Jurnal Edumath, Volume 6(2) th $2020 \mathrm{HIm}$. 66-72

ISSN Cetak : 2356-2064

ISSN Online : 2356-2056

\title{
DESIGN MEDIA PEMBELAJARAN MATEMATIKA SD MATHBIBUL ALAIHISALAM DI ERA COVID-19
}

\author{
Nurmitasari Nurmitasari ${ }^{1)}$, Robia Astuti ${ }^{2)}$, Naning Sutriningsih ${ }^{3)}$ \\ Program Studi Pendidikan Matematika, Universitas Muhammadiyah Pringsewu \\ email : nurmitasari@umpri.ac.id ${ }^{1)}$,robia.astuti@umpri.ac.id ${ }^{2)}$ \\ sutriningsihnaning024@ umpri.ac.id ${ }^{3)}$
}

\begin{abstract}
Abstrak
Tujuan penelitian ini yaitu untuk mengetahui kelayakan design media pembelajaran matematika SD Math BilBul "alaihisalam" (matematika bilangan bulat "ayo belajar operasi hitung secara islam") di era covid-19. Jenis penelitian ini adalah penelitian pengembangan yang mengacu pada tahapan pengembangan menurut Thiagarajan yang dikenal dengan model pengembangan 4-D yang terdiri dari empat tahapan yaitu define, design, develop, dan disseminate. Namun pada penelitian ini hanya sampai pada tahap develop. Develop yang dimaksud adalah pengembangan media berdasarkan penilaian ahli. Subjek penelitian yaitu seluruh siswa kelas IV SD Muhammadiyah yang berada di tingkat ranting Sukoharjo Pringsewu. Teknik pengumpulan data melalui instrumen berupa lembar validasi. Hasil dari penelitian ini adalah design media pembelajaran matematika SD Math BilBul "alaihisalam" (matematika bilangan bulat "ayo belajar operasi hitung secara islam") di era covid-19 layak digunakan.
\end{abstract}

Kata Kunci : Pembelajaran Matematika SD, Model Pengembangan 4D, Bilangan Bulat, NilaiNilai Islam

\begin{abstract}
The purpose of this study is to determine the feasibility of learning media design for Mathematics SD Math BilBul "alaihisalam" (integer mathematics "let's learn Islamic arithmetic operations") in the Covid-19 era. This type of research is development research which refers to the development stages according to Thiagarajan which is known as the 4-D development model which consists of four stages, namely define, design, develop, and disseminate. However, this research only reached the develop stage. Develop is meant by media development based on expert judgment. The research subjects were all fourth grade students of SD Muhammadiyah who were at the Sukoharjo Pringsewu branch level. Data collection techniques through instruments in the form of validation sheets. The result of this research is that the design of mathematics learning media at SD Math BilBul "alaihisalam" (integer mathematics "let's learn Islamic counting operations") in the Covid-19 era is feasible to use.
\end{abstract}

Keywords: Elementary School Mathematics Learning, 4D Development Model, Integer, Islamic Values

\section{PENDAhULUAN}

Pandemi covid-19 yang melanda di Negara Indonesia berdampak pada pendidikan, penutupan sementara lembaga pendidikan menjadi salah satu cara untuk menekan penyebaran penularan virus tersebut. Walaupun sekolah di tutup tetapi pembelajaran tetap harus berjalan. Langkah yang di tempuh yaitu dengan pembelajaran jarak jauh atau yang dikenal dengan 
pembelajaran daring. Albert (2020:2) menyatakan bahwa pembelajaran daring merupakan pembelajaran yang berlangsung didalam jaringan dimana pengajar dan pelajar tidak bertatap muka secara langsung. Pembelajaran daring membutuhkan bantuan jaringan internet melalui android atau komputer dan aplikasi tertentu seperti whatsApp, Zoom, google meeting dan lain sebagainya. Jadi Pembelajaran daring adalah suatu pembelajaran yang tidak bertatap muka secara langsung namun menggunakan bantuan jaringan internet melalui android atau komputer dan aplikasi tertentu seperti whatsApp, Zoom, google meeting dan lain sebagainya.

Namun pelaksanaan pembelajaran daring di lapangan yaitu SD Muhammadiyah Sukoharjo Pringsewu hanya sebatas mengirimkan file berupa foto materi yang ada pada buku guru atau kadang juga diselingi oleh video pembelajaran, kemudian siswa dituntut untuk memahami isi materi. Selanjutnya, siswa diberikan tugas yang hasilnya dikirimkan kembali melalui whatsapp grup. Hal ini menjadikan siswa merasa kesulitan dalam memahami materi yang diajarkan dan merasa bosan. Sri Harnani (2020: 1) bahwa beberapa guru di sekolah mengaku, jika pembelajaran daring ini tidak seefektif kegiatan pembelajaran tatap muka langsung, karena beberapa materi harus dijelaskan secara langsung, contohnya matematika. Selain itu materi yang disampaikan secara daring belum tentu bisa dipahami semua siswa. sistem ini hanya efektif untuk memberi penugasan.

Pihak lain salah satu wali siswa SD Muhammadiyah Sukoharjo Pringsewu mengeluhkan tentang sistem pembelajaran daring pada saat ini, dijelaskan bahwa anaknya di rumah lebih suka bermain game dibandingkan harus belajar materi yang diberikan oleh gurunya melalui whatsapp grup. Hal ini menjadikan wali siswa merasa khawatir dengan perkembangan kognitif anaknya terlebih perkembangan karakternya secara Islam. Tujuan Wali siswa menyekolahkan anaknya di Perguruan Muhammadiyah selain mendapatkan pengetahuan umum, namun mereka juga menginginkan agar anak-anak mereka tumbuh dengan karakter yang baik sesuai dengan nilai-nilai islam. Nurul Jempa (2017) menyatakan bahwa nilai-nilai islam pada hakekatnya adalah kumpulan prinsip-prinsip hidup, ajaran-ajaran tentang bagaimana manusia seharusnya menjalankan kehidupan didunia ini yang satu prinsip dengan yang lainnya saling terkait membentuk satu kesatuan yang utuh tidak dapat dipisahpisahkan. Kemudian Lukman Hakim (2012) 
nilai - nilai ajaran islam merupakan nilainilai yang akan mampu membawa manusia kepada kebahagiaan, kesejahteraan, keselamatan manusia baik dalam kehidupan di dunia maupun di akhirat. Dengan demikian nilai-nilai islam adalah suatu nilainilai yang menjadi pedoman hidup manusia dalam menjalani kehidupan didunia agar bahagia di dunia dan di akhirat nantinya.

Aspek nilai-nilai ajaran islam pada intinya dapat dibedakan menjadi tiga jenis, yaitu nilai-nilai aqidah, nilai-nilai ibadah, dan nilai-nilai akhlak. Nilai-nilai aqidah mengajarkan manusia untuk percaya adanya Allah Yang Maha Esa dan Maha Kuasa sebagai sang pencipta alam semesta, yang akan mengawasi dan memperhitungkan segala perbuatan manusia di dunia. Nilainilai ibadah mengajarkan pada manusia agar dalam setiap perbuatannya senantiasa dilandasi hati yang iklas guna mencapai rido Allah. Pengamalan konsep nilai-nilai ibadah akan melahirkan manusia-manusia yang adil, jujur, dan suka membantu sesamany. Nilai-nilai akhlak mengajarkan kepada manusia untuk bersikap dan berperilaku yang baik sesuai norma adab yang benar dan baik. Sehingga akan membawa pada kehidupan manusia yang tentram, damai, harmonis, dan seimbang.
Hasil penelitian Lukman Hakim (2017) menunjukkan bahwa (1) penerapan nilai-nilai islam untuk anak SD dari aspek ibadah dengan cara mengajak siswa berdoa bersama diawal dan akhir pembelajaran, mengontrol sholat siswa setiap hari, melaksanakan solat dhuhur dan ashar secara berjamaah disekolah, membimbing berdzikir setelah solat berjamaan; (2) pada aspek akhlak terlihat pada budaya sekolah yang dikembangkan yaitu: aku anak sholeh; rosulullah teladanku, menghormati orang tua dan guru, teman muslimku adalah saudara, membiasakan untuk beramal. (3) aspek aqidah yaitu penekanan sopan santun kepada orang tua dan guru, shodaqoh sebagai rasa syukur kepada Allah, menekankan sikap peduli dan selalu berprilaku hanya ditujukan karena Allah SWT.

Namun, dengan kondisi pembelajaran daring yang telah berjalan seperti yang telah dijelaskan, mereka menjadi khawatir tujuan mereka tidak tercapai. Kekhawatiran ini perlu dicarikan solusinya, walaupun siswa belajar di rumah namun siswa harus merasa senang dan tertarik dalam mengikuti pembelajaran serta tetap mendapat pendidikan karakter yang tertanam nilai-nilai islam sesuai dengan visi perguruan Muhammadiyah. Salah satu solusinya yaitu dengan merancang dan 
mendesain pembelajaran daring yang ringan dan efektif, dengan memanfaatkan perangkat atau media daring yang tepat dan sesuai dengan materi yang diajarkan. Menurut teori Piaget perkembangan kognitif siswa SD berada pada tahap operasional konkrit yaitu anak sudah cukup matang untuk menggunakan pemikiran logika atau operasi, tetapi hanya untuk objek fisik yang ada saat ini. (Ibda. 2015). Nurmitasari, dkk (2018) the introduction of mathematical consep in early childhood should be done by playing.

Untuk itu dalam tujuan dari penelitian ini adalah merancang atau mendesign media pembelajaran matematika SD dengan nama Math-bilbul "Alaihisalam" (matematika bilangan bulat "ayo belajar operasi hitung secara islam"), dan kemudian divalidasi oleh ahli untuk mengetahui kelayakan media tersebut sehingga dapat diterapkan pada pembelajaran matematika SD khususnya pada materi bilangan bulat. Media pembelajaran matematika SD Mathbilbul "Alaihisalam" adalah suatu media untuk mata pelajaran matematika pada materi bilangan bulat yang terintegrasi nilainilai islam. Bilangan bulat merupakan salah satu materi matematika yang sangat diperlukan dalam kehidupan sehari-hari. Salah satu sub materi bilangan bulat adalah penerapan bilangan bulat dalam kehidupan sehari-hari. Operasi hitung pada bilangan bulat adalah penjumlahan, pengurangan, perkalian, pembagian.

Media pembelajaran matematika SD Math-bilbul"Alaihisalam" memuat dua keuntungan sekaligus bagi para siswa. Keuntungan yang pertama adalah siswa dapat dengan mudah memahami konsep bilangan bulat tanpa harus bertatap muka secara langsung, keuntungan yang kedua adalah siswa mendapatkan nilai-nilai islam dengan harapan dapat menumbuhkan karakter siswa yang sesuai dengan nilai-nilai islam.

\section{METODE PENELITIAN}

Jenis penelitian ini adalah penelitian pengembangan yang mengacu pada tahapan pengembangan menurut Thiagarajan yang dikenal dengan model pengembangan 4-D (Trianto, 2009). Model pengembangan 4-D ini terdiri dari empat tahapan yaitu define, design, develop, dan disseminate. Namun pada penelitian ini hanya sampai pada tahap develop. (1) define, Tahap define adalah tahap pendefinisian yang terfokus pada analisis terhadap situsi yang dihadapi guru, karakteristik siswa, konsep-konsep yang akan diajarkan, dan diakhiri dengan tujuan pembelajaran. Adapun kegiatan pada tahap ini yaitu analisis awal-akhir, analisis siswa, analisis konsep, analisis tugas dan spesifikasi tujuan pembelajaran. (2) design, 
Tahap design yaitu tahap merancang media pembelajaran yang sesuai dengan situasi pembelajaran. Kegiatan pada tahap ini adalah: penyusunan tes, pemilihan media pembelajaran alternatif, dan pemilihan format. (3) develop, Tahap develop adalah tahap menghasilkan media pembelajaran yang layak digunakan melalui penilaian ahli. Penelitian ini dilaksanakan di SD Muhammadiyah yang ada di tingkat ranting Muhammdiyah Sukoharjo Pringsewu. Subjek penelitian ini adalah seluruh siswa kelas IV SD Muhammadiyah . Instrument dalam penelitian ini adalah lembar validasi. Lembar validasi digunakan untuk mengetahui kevalidan atau kelayakan media pembelajaran Math-bilbul "Alaihisalam" meliputi validitas isi yang mencakup semua desain media yang dikembangkan pada tahap develop dengan kriteria aspek penilaian (1) pada bidang keagamaan disesuaikan berdasarkan relevansi, keakuratan, konsep dasar materi, dan kesesuaian sajian dengan tuntutan pembelajaran yang berpusat pada siswa; (2) pada bidang pendidikan sekolah dasar meliputi kesesuaian materi dan bahasa yang digunakan; (3) pada bidang teknologi informasi meliputi kualitas grafis, kualitas tombol, efisiensi media, dan fungsi tombol.

\section{HASIL PENELITIAN DAN PEMBAHASAN}

Design yang dihasilkan pada penelitian ini adalah media pembelajaran matematika SD dengan nama Math-bilbul "Alaihisalam" (matematika bilangan bulat "ayo belajar operasi hitung secara islam”). Adapun langkah-langkah dalam mengembangkan media Mathbilbul"Alaihisalam mengikuti prosedur pengembangan model Thiagarajan yaitu define, design, dan develop. Hasil pengembangan pada tahap define adalah (1) pelaksanaan pembelajaran di SD Muhammadiyah Sukoharjo dilakukan secara daring guna memutus mata rantai penularan Virus Corona; (2) pembelajaran daring menuntut guru untuk kreatif membuat media pembelajaran yang menarik dan interaktif baik berbentuk video maupun PPT; (3) Materi yang sulit untuk dipahami adalah bilangan bulat; (4) Tujuan khusus wali murid menyekolahkan anaknya di SD Muhammadiyah Sukoharjo yaitu memiliki karakter yang sesuai dengan nilai-nilai islam; (5) karakteristik siswa kelas IV SD Muhammadiyah Sukoharjo adalah masih menyukai hal-hal yang bersifat konkret, mulai berlomba-lomba untuk berprestasi, masih senang bermain; (6) konsep-konsep yang diajarkan pada materi bilangan bulat untuk siswa kelas IV SD Muhammadiyah Sukoharjo yaitu memahami pengertian bilangan bulat, mengurutkan bilangan bulat, mengoperasikan bilangan bulat (perkalian, pembagian, penjumlahan, pengurangan dan campuran), serta mengaplikasikan operasi bilangan bulat dalam kehidupan sehari-hari; (7) pengembangan media pembelajaran matematika dibutuhkan oleh SD Muhammadiyah Sukoharjo; (8) tujuan pembelajaran yang ingin dicapai pada media pembelajaran matematika adalah siswa mampu memahami, mengoperasikan, dan 
mengaplikasikan bilangan bulat yang terintegrasi nilai-nilai islam baik secara ibadah maupun akidah dalam kehidupan sehari-hari.

Hasil pengembangan pada tahap design berupa lembar validasi ahli dan design media pembelajaran matematika SD. Lembar validasi ahli terdiri dari 3 ahli yaitu ahli agama, ahli materi dan ahli teknologi informatika yang menggunakan skala likert dengan ketentuan skor 1 hingga 4 . Untuk skor 1 artinya kurang baik, skor 2 artinya cukup baik, skor 3 artinya baik dan skor 4 artinya sangat baik.

Adapun kriteria penilaian pada aspek keagamaan meliputi (1) relevansi yaitu nilainilai islam yang termuat dalam media pembelajaran MathBilBul-Alaihisalam relevan dengan kompetensi yang harus dikuasai siswa, Nilai-nilai islam sesuai dengan tingkat perkembangan siswa SD kelas IV, Nilai-nilai islam sesuai tuntutan kurikulum, Ilustrasi nilainilai islam dalam media pembelajaran MathBilBul-Alaihisalam sesuai dengan tingkat perkembangan siswa SD kelas IV; (2) keakuratan, yaitu nilai-nilai islam yang disajikan sesuai dengan perkembangan mutakhir, nilainilai islam yang disajikan sesuai dengan kehidupan sehari-hari, pengemasan nilai-nilai islam dalam media pembelajaran MathBilBul Alaihisalam sesuai dengan pendekatan keilmuan yang bersangkutan (pendekatan saintifik); (3) konsep dasar materi, yaitu kesesuaian konsep nilai-nilai islam; (4) kesesuaian sajian dengan tuntutan pembelajaran yang berpusat pada siswa yaitu mendorong rasa keingintahuan siswa, mendorong terjadinya interaksi siswa, mendorong siswa membangun pengetahuannya sendiri, mendorong siswa belajar secara kelompok.

Kriteria penilaian pada aspek materi meliputi (1) kesesuaian materi yaitu tidak ada aspek indicator yang menyimpang, keluasan cakupan isi materi, kejelasan isi materi (berdasarkan indikator), uraian isi materi, kejelasan contoh yang disertakan; dan (2) bahasa yang digunakan yaitu Kejelasan bahasa yang digunakan,dan esesuaian Bahasa dengan sasaran pengguna.

Kriteria penilaian pada aspek teknologi informasi meliputi (1) kualitas grafis, yaitu tata letak teks dan gambar pada media pembelajaran, kesesuaian pemilihan background, kesesuaian pemilihan ukuran dan jenis huruf, kesesuaian warna, kemenarikan sajian gambar animasi, kesesuaian pemilihan gambar animasi dengan materi, kesesuaian pemilihan gambar animasi dengan materi; (2) kualitas tombol, yaitu kemenarikan tampilan tombol, dan keteraturan dan konsistensi tampilan tombol; (3) efisiensi media, yaitu kemudahan pemakaian program, kemudahan memilih menu program, kemudahan berinteraksi dengan program, kemudahan masuk dan keluar dari program; dan (4) fungsi tombol yaitu kemudahan memahami struktur tombol dan ketepatan reaksi tombol.

Beberapa tampilan design media pembelajaran matematika SD MathBilBulAlaihisalam terlihat pada gambar berikut. 


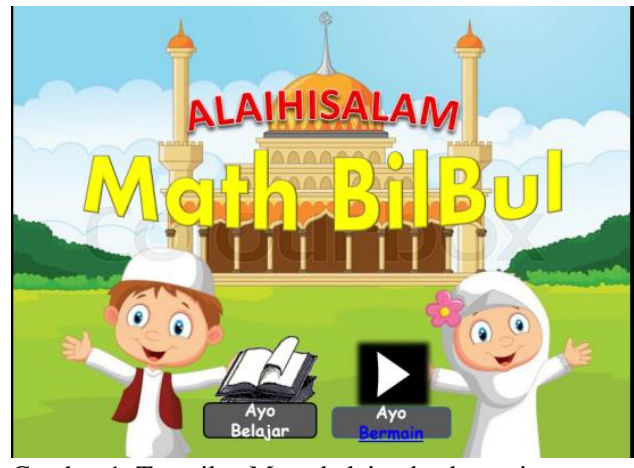

Gambar 1. Tampilan Menu belajar dan bermain

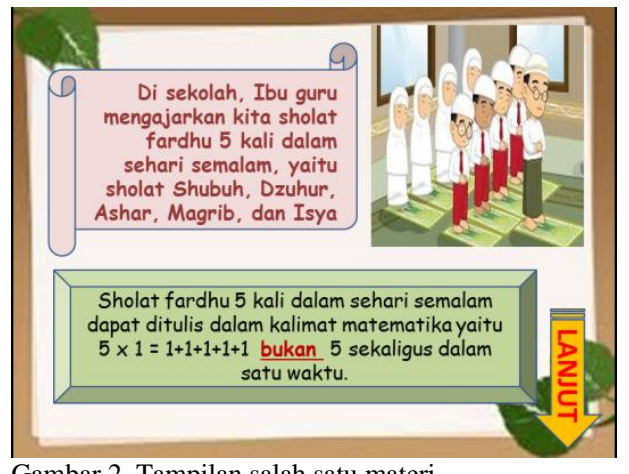

Gambar 2. Tampilan salah satu materi

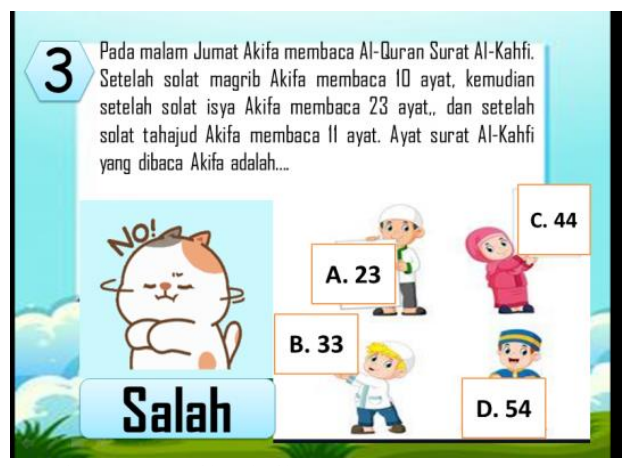

Gambar 3. Tampilan latihan

Hasil pengembangan pada tahap develop adalah hasil penilaian ahli terhadap media pembelajaran matematika SD MathBilBulAlaihisalam baik secara agama, materi, dan teknologi informatika. Penilai untuk pada aspek agama yaitu Nihayati, S.Pd, M.Pd.I selaku dosen AlIslam dan Kemuhammadiyahan, aspek materi yaitu Santi Hendayani, M.Pd, SD selaku dosen PGSD, dan teknologi informatika yaitu Roby Novianto, S.Kom.,
M.T.I . Adapun nilai validasi yang diberikan ahli yaitu 71,43 untuk aspek materi, 80,77 pada aspek keagamaan, dan 85,71 pada aspek teknologi informatika. Dari masing-masing aspek penilaian menunjukkan bahwa media pembelajaran sudah valid dan layak digunakan. Untuk itu media pembelajaran MathBilbul-Alaihisalam direkomendasikan untuk digunakan dalam pembelajaran daring di SD kelas IV.

\section{SIMPULAN}

Berdasarkan hasil penilaian ahli terhadap media pembelajaran matematika SD MathBilBul-Alaihisalam baik secara agama, materi, dan teknologi informatika. diperoleh bahwa design media pembelajaran matematika SD Math BilBul "alaihisalam" layak digunakan.

\section{DAFTAR PUSTAKA}

Harnani S 2020 Efektifitas Pembelajaran Daring di Masa Pandemi Covid-19 (BDK Jakarta: Kementrian Agama)

Ibda, F. (2015). Perkembangan Kognitif: Teori Jean Piaget. Jurnal Intelektualita, 3(1), 27-38.

Lukman Hakim (2012). Internalisasi NilaiNilai Agama Islam dalam Pembentukan Sikap dan Perilaku Siswa Sekolah Dasar Islam Terpadu Al-Muttaqin Kota Tasik Malaya. Jurnal Pendidikan Agama Islam Ta'lim Vol 10 No 1

Nurmitasari N, Noerhasmalina N, Rahayu S, dan Hidayatullah H 2018 Profil Of Character and Mathematic Concept On Children Game Proceeding International Conference On ChildFriendly Education Universitas Muhammadiyah Surakarta 
Nurul Jempa (2017). Nilai-nilai Agama Islam. Jurnal Ilmiah Pendidikan dan Pembelajaran Fakultas Tarbiah Universitas Muhammadiyah Aceh. Vo3 4 N6. 2.

Pohan A E 2020 Konsep Pembelajaran Daring berbasis pendekatan Ilmiah (Jawa Tengah: CV Sarnu Untung)

Suryadi 2020 Pembelajaran Era Disruptif Menuju Masyarakat 5.0 (Sebuah Telaah Perspektif Manajemen PendidikanPro siding Seminar Nasional Pendidikan Program Pascasarjana Universitas PGRI Palembang

Trianto 2009 Mendesain Model Pembelajaran Inovatif Progresif (Jakarta: kencana prenada media grup) 